\title{
Gradation Analysis of Reclaimed Asphalt Pavement from National Road as Asphalt Concrete Layer
}

\author{
Ari Widayanti ${ }^{1, a)}$, Ria Asih Aryani Soemitro ${ }^{2, b)}$, Januarti J. Ekaputri ${ }^{2, c)}$ \& Hitapriya \\ Suprayitno $^{2 . d)}$ \\ ${ }^{1)}$ Doctorate Student, Institut Teknologi Sepuluh Nopember, Surabaya \\ ${ }^{2)}$ Civil Engineering Department, Institut Teknologi Sepuluh Nopember, Surabaya \\ Correspondent : a) ariwidayanti1973@gmail.com, ${ }^{b}$ ria@ce.its.ac.id, ${ }^{c}$ januartije@gmail.com \& \\ ${ }^{\mathrm{d})}$ suprayitno.hita@gmail.com
}

\begin{abstract}
ABSTRAK
One of the assets of land transportation infrastructure that obtained attention now is the road. Road construction can support the developing economy, industry, trade, people and good mobility, regional development. Management of road infrastructure assets require to prioritize natural resources managements efficiently as possible. Reclaimed Asphalt Pavement (RAP) is the result of dredging material with aggregate gradation condition that are not in accordance with the needs of the gradation envelope. Utilization of RAP as a pavement layer is an effort to converse the use of natural materials. The efficiency aspect of RAP aggregate use needs to be done by determining the road pavement layer that is most appropriate to the condition of the RAP aggregate so that the addition of new aggregates is kept to a minimum. The aim of this study was to obtain a suitable pavement layer determination based on the aggregate gradation of RAP and standard specifications.

The method used literature study from previous research and RAP aggregate sieve analysis from national roads in East Java Province. The results showed that the utilization of RAP from national roads based on the RAP aggregate conformance value were AC-WC layer of $82.292 \%$, AC-BC layer of $68.75 \%$ and AC-Base layer of $41.667 \%$. Based on the gradation analysis, it is found that the RAP aggregate is best suited for the AC-WC layer, because it requires optimal RAP aggregate and the most efficient of additional aggregate.
\end{abstract}

Keywords : infrastructure asset management, pavement, road, gradation, reclaimed asphalt pavement.

\section{INTRODUCTION}

Road as one of the assets of land transportation infrastructure. Road construction that is currently involves adequate material availability. For the efficient use of natural materials, the use of environmental waste based materials needs to be optimized so that it can save on the use of natural materials, especially natural aggregates. Reclaimed Asphalt Pavement (RAP) is a result of scouring the road pavement with Cold Milling Machine, it can be done by milling or full depth removal. The large potential of RAP in East Java Province is around 50,000 m3/year, making this material increasingly piling up and its utilization needs to be increased again. Simples uses include the use of RAP for road shoulders, parking areas, entrances to residential and office location.

The extraction process is a process to separate RAP aggregate from RAP asphalt. From this process, the percentage of bitumen contained in RAP can be obtained, and sieve analysis separating RAP asphalt with it constituent substances. The aggregates consist of coarse, 
medium and fine fraction materials with sizes $(10 / 20),(5 / 10),(0 / 5)$. The aggregate is a mixture of road pavement components with the largest percentage of $90-95 \%$ in weight percentage, $75-85 \%$ in volume percentages.

The utilization of RAP decrease the accumulation of RAP therefore it does not damage the environment, cost efficiency, reduce the use of natural resources, reduce the rate of damage caused by mining and quarrying (Budianto, 2009). The use of RAP increases volumetric, mechanical and properties of mixtures (Shen et al, 2007), affects the road technical life and damage resistance (Xiao et al, 2007), increases stability (Parvez et al, 2008), produce better workability and stability (Xiao et al, 2009). The use of RAP reduces the requirement to dispose of old road pavements, and preserves the availability of natural asphalt and aggregate. It has an impact on saving production costs and increasing profits for the community (TRB, 2011). The use of RAP is beneficial for environmental sustainability, it has the ability to produce optimum mixed performance (Widger et al, 2012), improve mixed performance (Pradyumma et al, 2013).

On the other hand the weakness of RAP is that the RAP gradation is not included in the standard gradation curve (Herawati, 2012; Kusmarini, 2012; Handayani, 2016), ductility is not in accordance with standards (Falevi, 2012; Herawati, 2012; Kusmarini, 2012; Wibowo, 2012; Harahab, 2013; Sujiartono, 2014), penetration is not in accordance with standards (Falevi, 2012; Herawati, 2012; Kusmarini, 2012; Wibowo, 2012; Harahab, 2013; Sujiartono, 2014; Handayani, 2016). The other studies stated the use of RAP increases brittleness of pavement mixtures (Parveez, 2008). In the pavement mixture, it does not produce consistency changes in the addition of physical properties mixtures in the aspect of penetration, ductility and softening point. In this case, the research support in microstructural aspects is required therefore it can improve the technical performance of pavement mixtures (Sunil et al, 2014).

In terms of utilizing RAP as a more efficient pavement material, a study of RAP aggregate grading from national roads in East Java and the selection of road pavement layers that are suitable for RAP gradation is required so that the potential utilization of RAP is more optimal and the demand for additional natural aggregates can be minimized.

\section{LITERATURE REVIEW}

Reclaimed Asphalt Pavement define as a result of dredging the pavement layer with Cold Milling Machine, it can be done by Milling or full depth removal (TRB, 2011).

HMA mixed planning containing RAP requires testing that is important to obtain the characteristics of RAP. To obtain an efficient design and produce a mixture with RAP. RAP properties are required as follows asphalt levels in RAP, RAP aggregate gradations, RAP specific gravity aggregate, RAP particle coarse aggregate particles, flaky and elongated particle of RAP coarse aggregate, angularity of RAP fine aggregate (TRB, 2011).

The extraction process is the process of separating aggregates and asphalt in RAP using an Extractor Solvent tool. The RAP recovery process is the process of separating the asphalt with its constituent substances.

The aggregate consists of coarse aggregate with a size of $10 / 20 \mathrm{~mm}$, medium aggregate with a size of $5 / 10 \mathrm{~mm}$ and fine aggregate with a size of $0 / 5 \mathrm{~mm}$. Aggregate gradation is a mixture of road pavement components with the largest percentages of $90-95 \%$ in weight percentages and $75-85 \%$ in volume percentages. Aggregate gradation is the aggregate grain size distribution expressed as a percent of total aggregate weight. The aggregate gradation is obtained by sieve analyzing from the aggregate filtering process with various sieve size. Gradation is likely to be important in aggregate properties. This will affect the properties of HMA, including stiffness, stability, durability, permeability, workability, fatigue resistance, friction resistance and resistance to damage. Therefore gradation is the main consideration in HMA/Hot Mix Asphalt planning. Aggregate gradations consist of uniform/open/uniformly 
graded, good graded/dense graded, gap graded (NAPA, 1996). Uniformly graded is a gradation with almost the same size aggregate, containing fine aggregates that are few in number therefore they can not fill the voids of aggregates. They will produce a layer of pavement with high permeability, low stability, small volume weight. Dense graded is gradation with a mixture of coarse and fine aggregates in a balanced proportion. It results in a high stability of road pavement layer, less waterproof, poor drainage, large volume weight. Gap graded is a gradation with an aggregate mixture with one fraction lost or very little fraction (Sukirman, 1995).

Asphalt Concrete is a continuous graded of asphalt concrete, for roads with heavy traffic. The most important characteristic is stability. Asphalt Concrete is divided into 3 layers, namely $\mathrm{AC}-\mathrm{WC}$ (Asphalt Concrete - Wearing Coarse), AC-BC (Asphalt Concrete - Binder Coarse), AC-Base (Asphalt Concrete- Base). AC-WC or wearing layer with a minimum thickness of $4 \mathrm{~mm}$, AC-BC or binder layer with a minimum thickness of $5 \mathrm{~mm}$, AC-Base or foundation layer with a minimum thickness 6 $\mathrm{mm}$ (Sukirman, 2003). The combined aggregate gradation envelope for a mixture of Asphalt Concrete based on the Bina Marga Specification 2018 is presented in Table

Table 1. Gradation Envelope of Combined Aggregate in Asphalt Concrete

\begin{tabular}{|c|c|c|c|c|}
\hline \multirow{2}{*}{$\begin{array}{l}\text { Sieve Size } \\
\quad(\mathrm{mm})\end{array}$} & \multirow{2}{*}{$\begin{array}{l}\text { Sieve Size } \\
\text { (inch) }\end{array}$} & \multicolumn{3}{|c|}{ Asphalt Concrete/AC } \\
\hline & & $\begin{array}{c}\text { Wearing } \\
\text { Coarse/WC }\end{array}$ & $\begin{array}{c}\text { Binder } \\
\text { Coarse } / \text { BC }\end{array}$ & Base Coarse \\
\hline 37.5 & $11 / 2 ”$ & - & - & 100 \\
\hline 25 & $1 "$ & - & 100 & $90-100$ \\
\hline 19 & $3 / 4 "$ & 100 & $90-100$ & $76-90$ \\
\hline 12.5 & $1 / 2 "$ & $90-100$ & $75-90$ & $60-78$ \\
\hline 9.5 & $3 / 8^{\prime \prime}$ & $77-90$ & $66-82$ & $52-71$ \\
\hline 4.75 & 4 & $53-69$ & $46-64$ & $35-54$ \\
\hline 2.36 & 8 & $33-53$ & $30-49$ & $23-41$ \\
\hline 1.18 & 16 & $21-40$ & $18-38$ & $13-30$ \\
\hline 0.6 & 30 & $14-30$ & $12-28$ & $10-22$ \\
\hline 0.3 & 50 & $9-22$ & $7-20$ & $6-15$ \\
\hline 0.15 & $\# 100$ & $6-15$ & $5-13$ & $4-10$ \\
\hline 0.075 & $\# 200$ & $4-9$ & $4-8$ & $3-7$ \\
\hline
\end{tabular}

Source: Bina Marga Specification (2018)

\section{METHOD}

The methods of collecting data used literature studies of previous research on RAP from national roads in East Java Province. The RAP material come from previous research and current research by sieve analyzing from Margomulyo - Surabaya, Waru - Taman Sidoarjo, Gemekan - Jombang, Pandaan - Malang, Pilang - Probolinggo locations.

\section{RESULT AND DISCUSSION}

Based on the results of the RAP aggregate sieve analysis originating from several sources locations of RAP , the following results are presented in Table 2, Table 3 and Table 4. 
Table 2. RAP Aggregate Gradation for Asphalt Concrete - Wearing Course

\begin{tabular}{|c|c|c|c|c|c|c|c|c|c|c|}
\hline \multirow{2}{*}{ Lower } & \multirow{2}{*}{ Upper } & ZMS & WWT & HWT & KGJ & KPM & HPP & FPM & WPM & \multirow[b]{2}{*}{ Sieve } \\
\hline & & $\%$ Passing & $\%$ Passing & $\%$ Passing & \% Passing & $\%$ Passing & \% Passing & $\%$ Passing & $\%$ Passing & \\
\hline 100 & 100 & 100.00 & 100.00 & 100.00 & 100.00 & 100.00 & 100.00 & 100.00 & 100.00 & $11 / 2^{\prime}$ \\
\hline 100 & 100 & 100.00 & 100.00 & 100.00 & 100.00 & 100.00 & 100.00 & 100.00 & 100.00 & $1 "$ \\
\hline 100 & 100 & 100.00 & 100.00 & 100.00 & 100.00 & 100.00 & 100.00 & 100.00 & 100.00 & $3 / 4 "$ \\
\hline 90 & 100 & 97.40 & 93.29 & 100.00 & 97.30 & 96.91 & 97.08 & 98.70 & 98.70 & $1 / 2 "$ \\
\hline 77 & 90 & 93.10 & 82.22 & 85.34 & 90.53 & 86.56 & 91.93 & 93.29 & 93.29 & $3 / 8$ \\
\hline 53 & 69 & 67.20 & 51.75 & 51.64 & 42.61 & 50.37 & 68.15 & 72.16 & 72.16 & $\# 4$ \\
\hline 33 & 53.0 & 49.00 & 35.68 & 35.91 & 29.01 & 28.74 & 44.48 & 47.78 & 47.78 & $\# 8$ \\
\hline 21 & 40.0 & 35.00 & 26.08 & 27.08 & 22.48 & 19.69 & 31.56 & 34.01 & 34.01 & $\# 16$ \\
\hline 14 & 30.0 & 25.30 & 21.10 & 20.88 & 17.75 & 15.36 & 23.34 & 25.79 & 25.79 & \# 30 \\
\hline 9 & 22.0 & 18.40 & 15.62 & 15.56 & 12.28 & 11.06 & 16.37 & 19.27 & 19.27 & \# 50 \\
\hline 6 & 15 & 12.80 & 11.02 & 10.18 & 6.94 & 6.86 & 10.44 & 13.67 & 13.67 & $\# 100$ \\
\hline 4 & 9 & 3.50 & 6.89 & 5.00 & 2.25 & 2.49 & 6.27 & 8.70 & 8.70 & $\# 200$ \\
\hline \multicolumn{2}{|c|}{ Conformity (\%) } & 83.333 & 91.667 & 91.667 & 66.667 & 66.667 & 91.667 & 83.333 & 83.333 & \\
\hline \multicolumn{2}{|c|}{ Average (\%) } & 82.292 & & & & & & & & \\
\hline
\end{tabular}

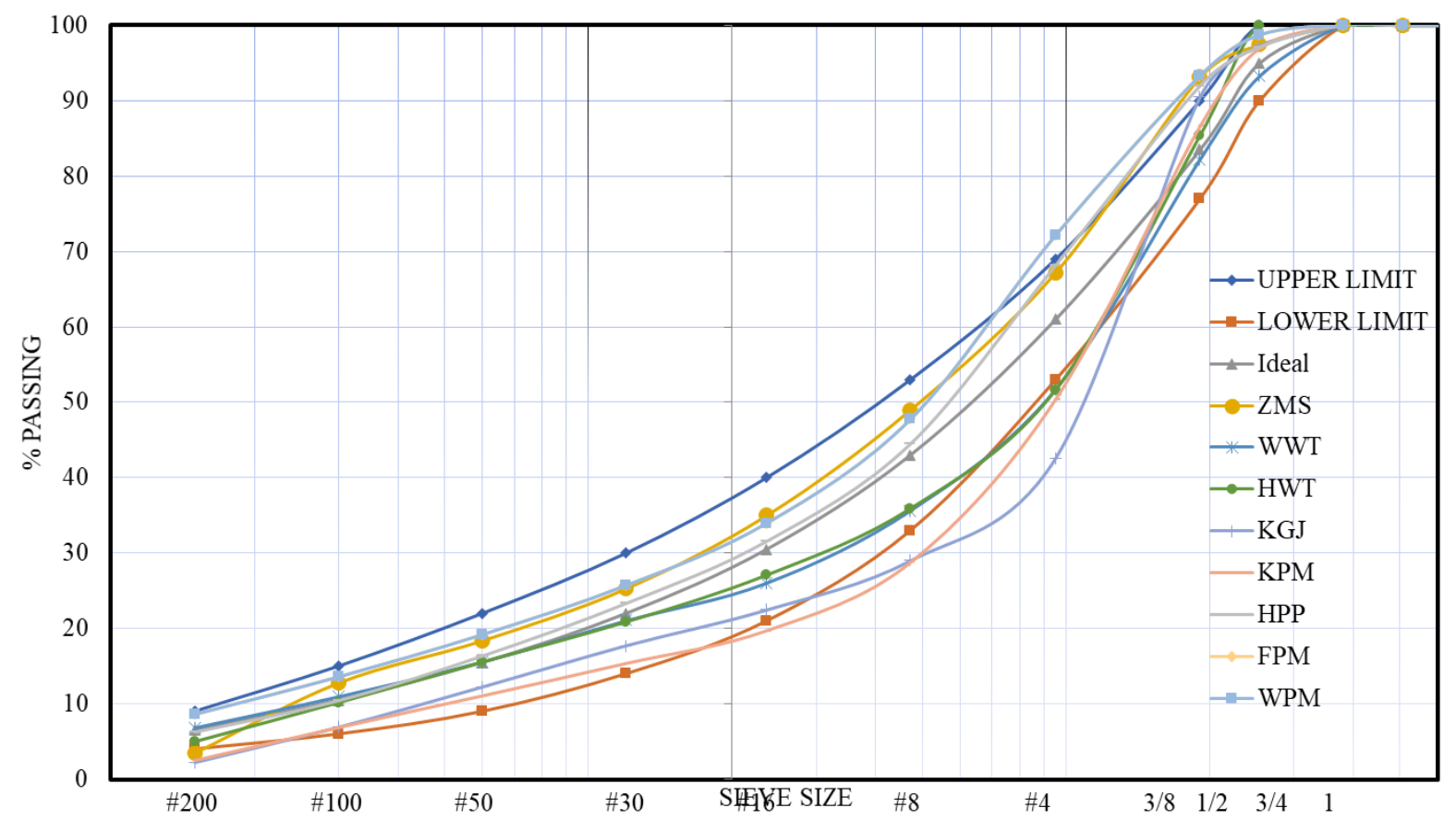

Figure 1. RAP Aggregate Gradation for Asphalt Concrete Wearing Course

\section{Note:}

ZMS : Zhain Margomulyo - Surabaya

WWT : Widayanti Waru - Taman

HWT : Handayani Waru - Taman

KGJ : Kusmarini Gemekan - Jombang
KPM : Kusmarini Pandaan - Malang

HPP : Herawati Pilang - Probolinggo

FPM : Falevi Pandaan - Malang

WPM : Wibowo Pandaan - Malang 
Table 3. RAP Aggregate Gradation for Asphalt Concrete - Binder Coarse

\begin{tabular}{|c|c|c|c|c|c|c|c|c|c|c|}
\hline \multirow{2}{*}{ Lower } & \multirow{2}{*}{ Upper } & ZMS & WWT & HWT & KGJ & KPM & HPP & FPM & WPM & \multirow[b]{2}{*}{ Sieve } \\
\hline & & $\%$ Passing & $\%$ Passing & $\%$ Passing & $\%$ Passing & $\%$ Passing & $\%$ Passing & \% Passing & $\%$ Passing & \\
\hline 100 & 100 & 100.00 & 100.00 & 100.00 & 100.00 & 100.00 & 100.00 & 100.00 & 100.00 & $11 / 2 "$ \\
\hline 100 & 100 & 100.00 & 100.00 & 100.00 & 100.00 & 100.00 & 100.00 & 100.00 & 100.00 & $1 "$ \\
\hline 90 & 100 & 100.00 & 100.00 & 100.00 & 100.00 & 100.00 & 100.00 & 100.00 & 100.00 & $3 / 4 "$ \\
\hline 75 & 90 & 97.40 & 93.29 & 100.00 & 97.30 & 96.91 & 97.08 & 98.70 & 98.70 & $1 / 2 "$ \\
\hline 66 & 82 & 93.10 & 82.22 & 85.34 & 90.53 & 86.56 & 91.93 & 93.29 & 93.29 & $3 / 8$ \\
\hline 46 & 64 & 67.20 & 51.75 & 51.64 & 42.61 & 50.37 & 68.15 & 72.16 & 72.16 & $\# 4$ \\
\hline 30 & 49.0 & 49.00 & 35.68 & 35.91 & 29.01 & 28.74 & 44.48 & 47.78 & 47.78 & $\# 8$ \\
\hline 18 & 38.0 & 35.00 & 26.08 & 27.08 & 22.48 & 19.69 & 31.56 & 34.01 & 34.01 & $\# 16$ \\
\hline 12 & 28.0 & 25.30 & 21.10 & 20.88 & 17.75 & 15.36 & 23.34 & 25.79 & 25.79 & \# 30 \\
\hline 7 & 20.0 & 18.40 & 15.62 & 15.56 & 12.28 & 11.06 & 16.37 & 19.27 & 19.27 & \# 50 \\
\hline 5 & 13 & 12.80 & 11.02 & 10.18 & 6.94 & 6.86 & 10.44 & 13.67 & 13.67 & $\# 100$ \\
\hline 4 & 8 & 3.50 & 6.89 & 5.00 & 2.25 & 2.49 & 6.27 & 8.70 & 8.70 & \# 200 \\
\hline \multicolumn{2}{|c|}{ Conformity (\%) } & 66.667 & 83.333 & 83.333 & 58.333 & 66.667 & 75.000 & 58.333 & 58.333 & \\
\hline \multicolumn{2}{|c|}{ Average (\%) } & 68.750 & & & & & & & & \\
\hline
\end{tabular}

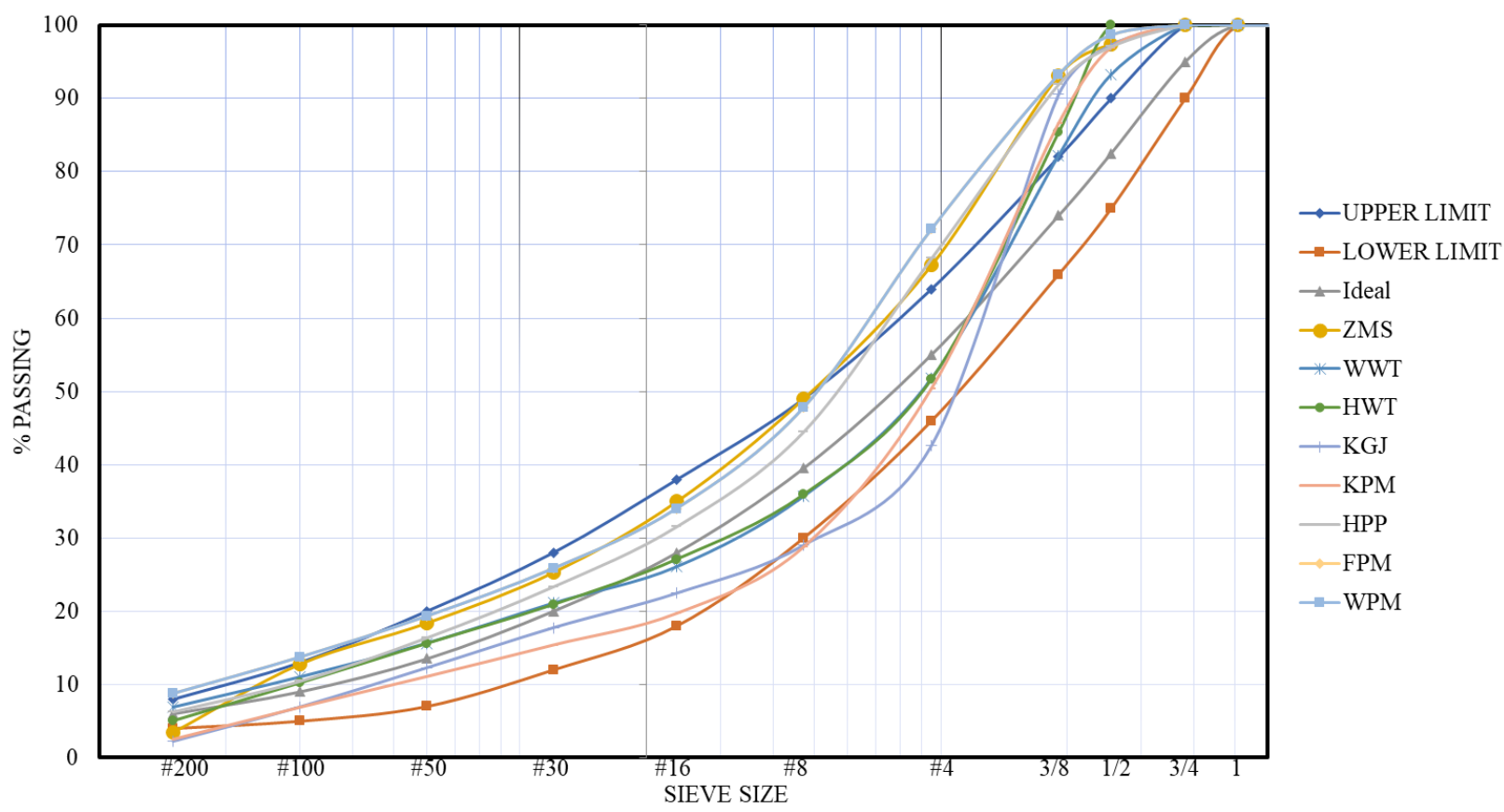

Figure 2. RAP Aggregate Gradation for Asphalt Concrete - Binder Coarse 
Table 4. RAP Aggregate Gradation for Asphalt Concrete - Base Course

\begin{tabular}{|c|c|c|c|c|c|c|c|c|c|c|}
\hline \multirow{2}{*}{ Lower } & \multirow{2}{*}{ Upper } & ZMS & WWT & HWT & KGJ & KPM & HPP & FPM & WPM & \multirow[b]{2}{*}{ Sieve } \\
\hline & & \% Passing & $\%$ Passing & $\%$ Passing & $\%$ Passing & $\%$ Passing & $\%$ Passing & $\%$ Passing & $\%$ Passing & \\
\hline 100 & 100 & 100.00 & 100.00 & 100.00 & 100.00 & 100.00 & 100.00 & 100.00 & 100.00 & $11 / 2 "$ \\
\hline 90 & 100 & 100.00 & 100.00 & 100.00 & 100.00 & 100.00 & 100.00 & 100.00 & 100.00 & $1 "$ \\
\hline 76 & 90 & 100.00 & 100.00 & 100.00 & 100.00 & 100.00 & 100.00 & 100.00 & 100.00 & $3 / 4 "$ \\
\hline 60 & 78 & 97.40 & 93.29 & 100.00 & 97.30 & 96.91 & 97.08 & 98.70 & 98.70 & $1 / 2 "$ \\
\hline 52 & 71 & 93.10 & 82.22 & 85.34 & 90.53 & 86.56 & 91.93 & 93.29 & 93.29 & $3 / 8$ \\
\hline 35 & 54 & 67.20 & 51.75 & 51.64 & 42.61 & 50.37 & 68.15 & 72.16 & 72.16 & $\# 4$ \\
\hline 23 & 41.0 & 49.00 & 35.68 & 35.91 & 29.01 & 28.74 & 44.48 & 47.78 & 47.78 & $\# 8$ \\
\hline 13 & 30.0 & 35.00 & 26.08 & 27.08 & 22.48 & 19.69 & 31.56 & 34.01 & 34.01 & $\# 16$ \\
\hline 10 & 22.0 & 25.30 & 21.10 & 20.88 & 17.75 & 15.36 & 23.34 & 25.79 & 25.79 & \# 30 \\
\hline 6 & 15.0 & 18.40 & 15.62 & 15.56 & 12.28 & 11.06 & 16.37 & 19.27 & 19.27 & \# 50 \\
\hline 4 & 10 & 12.80 & 11.02 & 10.18 & 6.94 & 6.86 & 10.44 & 13.67 & 13.67 & $\# 100$ \\
\hline 3 & 7 & 3.50 & 6.89 & 5.00 & 2.25 & 2.49 & 6.27 & 8.70 & 8.70 & $\# 200$ \\
\hline \multicolumn{2}{|c|}{ Conformity (\%) } & 25.000 & 58.333 & 58.333 & 66.667 & 66.667 & 25.000 & 16.667 & 16.667 & \\
\hline \multicolumn{2}{|c|}{ Average (\%) } & 41.667 & & & & & & & & \\
\hline
\end{tabular}

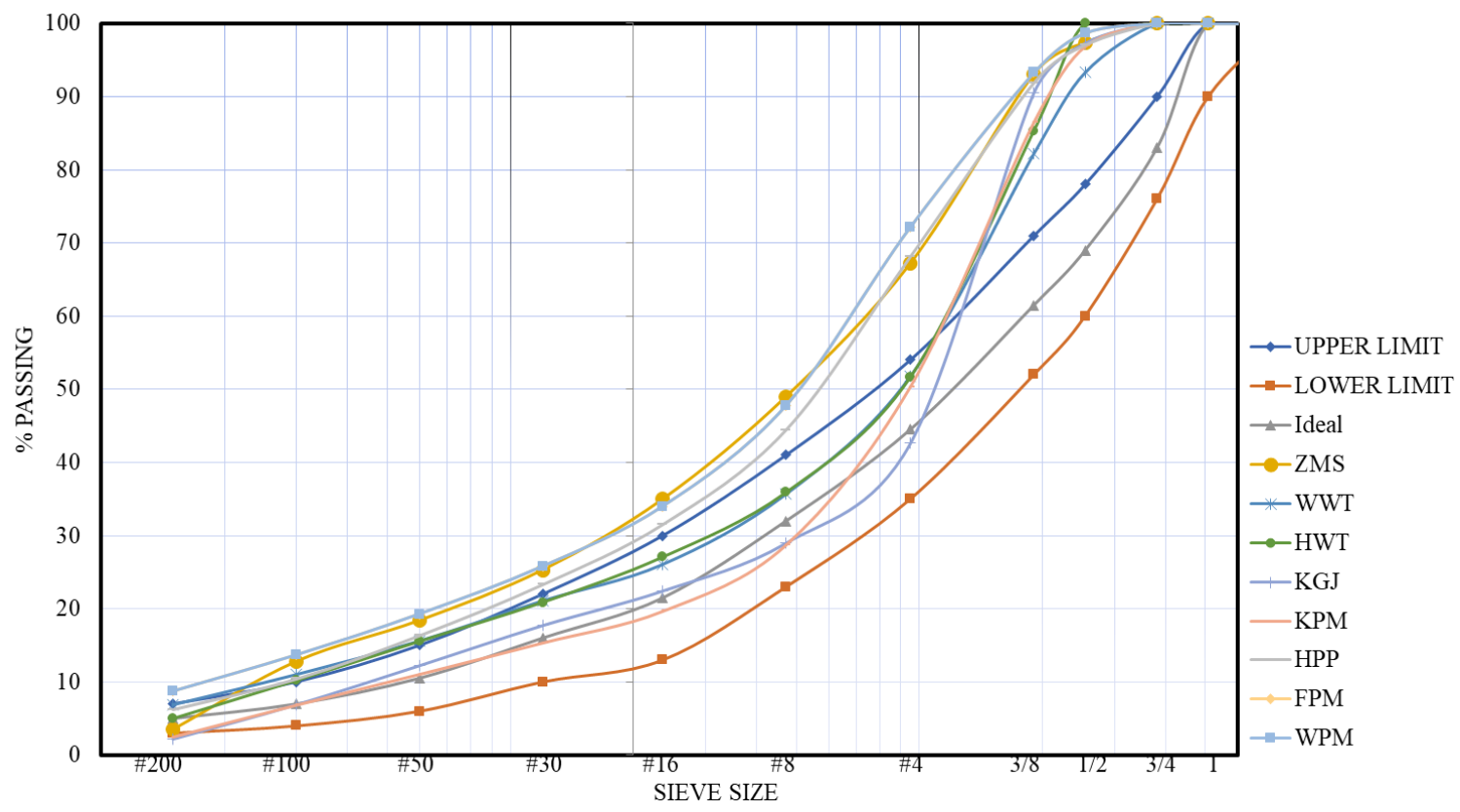

Figure 3. RAP Aggregate Gradation for Asphalt Concrete - Base Course

Based on the Table 2, Table 3, Table 4 and Figure 1, Figure 2 and Figure 3, it was found that the aggregate gradation of RAP originating from the National Road in East Java Province showed the highest suitability used for the AC-WC layer of $82.292 \%$, the AC-BC layer of $68.750 \%$ and the AC-Base layer of $41.667 \%$.

The aggregate gradation showed that many subtle sizes which require the most fine aggregates were for the AC-WC or surface layer. It was due to the fact that the aggregate RAP has experienced degradation and disintegration due to traffic loads, chemical effect due to the influence of weather (rain and heat), temperature and environment therefore its size does not match the previous condition.

The location of the RAP also determined the suitability of the use of the road pavement layer. In the AC-WC layer with suitability $91.667 \%$ was obtained from the RAP location from Waru-Taman, and Pilang-Probolinggo. It showed that many RAPs obtained in this location were smooth and suitable for the AC-WC layer. In the AC-BC layer with a suitability value of $83.333 \%$ obtained from the RAP Waru-Taman Sidoarjo. The RAP from Waru-Taman Sidoarjo location also matched the AC-BC layer. Whereas the AC-Base layer with $66.667 \%$ 
conformity value was obtained from Gemekan-Jombang and Pandaan-Malang. It indicated that the Gemekan-Jombang and Pandaan Malang location were still found in large size materials and suitable for the Base -Coarse layer.

\section{CONCLUSIONS}

Based on the results of data collection, analysis and discussion, the conclusions obtained from this study are:

- Based on the size of the RAP aggregate, the RAP from national roads of East Java Province is best used for the AC-WC layer with a suitable value of $82.292 \%$, AC-BC layer with a suitable value of $68.750 \%$ and AC-Base layer with a suitable value of $41.667 \%$.

- The location of the origin of RAP also determines the suitability of the pavement layer. follows.

Based on the conclusions above, two main recommendation that can be formulated as

- Determination of the appropriate pavement layer also requires an analysis of the quality of RAP properties including the quality of asphalt and aggregate of RAP. In this case, because RAP is a residual material, the adjustments are for the AC-BC and AC-Base layer and not the AC-WC layer which is directly faced with loads, vehicle loads and traffic loads, as well as weather, temperature and rain effects on the pavement layer.

- The use of RAP must also consider the age of asphalt with the addition of additives and new asphalt, as well as new aggregates so as to obtain better asphalt performance.

ACKNOWLEDGMENT. The writing of this study is supported by several literature studies which aim to obtain gradations of Reclaimed Asphalt Pavement therefore it is suitable and efficient for the Asphalt Concrete layer. We express our deepest gratitude to the researchers whose work has become a reference in writing this article.

\section{REFERENCES}

Bina Marga. (2018). Spesifikasi Umum Bina Marga Tahun 2018. Direktorat Jenderal Bina Marga Kementerian Pekerjaan Umum. Jakarta.

Budianto, H. (2009). Menuju Jalan yang Andal, PT. Cakra Daya Sakti. Surabaya.

Departemen Pemukiman dan Prasarana Wilayah. (2002). Manual Pekerjaan Campuran Beraspal Panas. Direktorat Jenderal Prasarana Wilayah. Jakarta.

Falevi, R. (2012). Optimalisasi Penggunaan Reclaimed Asphalt Pavement (RAP) sebagai Bahan Campuran Beraspal Panas (Asphaltic Concrete) Tipe AC-Wearing Course (ACWC) Gradasi Halus dengan Menggunakan Aspal Pen 60-70 Variasi Abrasi Agregat Baru (Studi Kasus Jalan Nasional Pandaan - Malang). Tesis Pasca Sarjana. Institut Teknologi Sepuluh Nopember Surabaya.

Handayani, R. (2016). "Analisa Penggunaan Reclaimed Asphalt Pavement (RAP) sebagai Bahan Campuran Beraspal Panas Tipe Asphalt Concrete-Binder Course (ACBC) dengan Menggunakan Fly Ash (Studi Kasus Ruas Jalan Taman Waru)". Tesis Pasca Sarjana. Institut Teknologi Sepuluh Nopember Surabaya.

Harahab, S. Soemitro, R.A.A, Budianto, H. (2013). “Optimalisasi Penggunaan Reclaimed Asphalt Pavement (RAP) sebagai Bahan Campuran Beraspal Panas (Asphaltic Concrete) Tipe AC-Wearing Course (AC-WC) Gradasi Kasar dengan Aspal Pen 60-70 dan Aspal Modifikasi Jenis TRS 55 (Studi Kasus Jalan Nasional Pandaan-Malang dan Jalan Nasional Pilang-Probolinggo)". Prosiding Seminar Nasional Pascasarjana XIII ITS, Surabaya 15 Agustus 2013, ISBN No. 978-979-96700-6-9.

Herawati, N., Soemitro, R.A.A., Budianto, H. (2012). "Analisis Penentuan Komposisi Optimal Penggunaan Reclaimed Asphalt Pavement (RAP) sebagai Bahan Campuran 
Beraspal Panas (Asphaltic Concrete) Menggunakan Aspal Modifikasi (Studi Kasus Jalan Pilang - Probolinggo)". Prosiding Seminar Nasional Aplikasi Teknologi Prasarana Wilayah (ATPW) Surabaya, 11 Juli 2012. ISSN 2301-6752, Material Bahan Bangunan dan Konstruksi, hal. F-1.

Kusmarini, E.P., Soemitro, R.A.A., Budianto, H. (2012). “Analisis Penggunaan Reclaimed Asphalt Pavement (RAP) dan Aspal Pen 60 - 70 sebagai Bahan Campuran Beraspal Panas (Asphaltic Concrete) (Studi Kasus Ruas Jalan Gemekan - Jombang dan Pandaan - Malang)". Prosiding Seminar Nasional Aplikasi Teknologi Prasarana Wilayah (ATPW) Surabaya, 11 Juli 2012, ISSN 2301-6752, Material Bahan Bangunan dan Konstruksi, hal. F-5 - F-10.

National Asphalt Pavement Association - NAPA (1996). Hot Mix Asphalt Materials Mixture Design and Construction. NAPA Education Foundation. Maryland

Ortiz, O. R. Berardinelli, A., Carvajal-M., Fuentes, L.G. (2012). "Evaluation of Hot Mix Asphalt Mixtures with Replacement of Aggregates by Reclaimed Asphalt Pavement (RAP) Material”, Procedia Sosial and Behavioral Sciences 53, hal. 379-388.

Parveez, Prateek, Srikanta, Yathiraj, Konnur, Dinesh, (2013). "Study on the Effect of Reclaimed Asphalt Pavement (RAP) on the Mechanical Behaviour of Hot Mix Asphalt", India.

Pradyumna, T Anil. Mittal, Abhishek, Jain, P.K. (2013). "Characterization of Reclaimed Asphalt Pavement (RAP) for Use in Bituminous Road Construction”, Procedia-Social and Behavioral Sciences 104, hal. 1149-1157.

Shen, J., Amirkhanian, S., Aune, J.M. (2007). "Effects of Rejuvenatin Agents of Superpave Mixtures Containing Reclaimed Asphalt Pavement". Journal of Materials in Civil Engineering. ASCE. May. 2007.

Sujiartono, A. (2014). Optimalisasi Penggunaan Reclaimed Asphalt Pavement (RAP) sebagai sebagai Bahan Campuran Beraspal Panas (Asphaltic Concrete) Tipe AC-Binder Course (AC-BC) dan AC-Base Course (AC-Base) dengan Menggunakan Aspal Modifikasi Asbuton (BNA-Blend) (Studi Kasus Jalan Nasional Pilang-Probolinggo). Tesis Pasca Sarjana. Institut Teknologi Sepuluh Nopember Surabaya.

Sukirman, S. (1995). Perkerasan Lentur Jalan Raya, Penerbit Nova. Bandung.

Sukirman, S. (2003). Beton Aspal Campuran Panas, Penerbit Granit. Jakarta.

Suwantoro (2010). Optimalisasi Penggunaan Material Hasil Cold Milling untuk Daur Ulang Lapisan Perkerasan Beton Aspal Tipe AC (Asphaltic Concrete). Tesis Pasca Sarjana. Institut Teknologi Sepuluh Nopember Surabaya.

TRB (2011). A Manual for Design of Hot Mix Asphalt with Commentary. National Cooperative Highway Research Program. NCHRP Report 673. Transportation Research Board. Washington DC.

Wibowo, H.W. (2012). Optimalisasi Penggunaan Reclaimed Asphalt Pavement (RAP) sebagai Material Campuran pada Asphaltic Concrete Tipe AC-BC dan AC-Base dengan Pen 60-70 (Studi Kasus Jalan Nasional Pandaan - Malang). Tesis Pasca Sarjana. Institut Teknologi Sepuluh Nopember Surabaya.

Widayanti, A., Soemitro, R.A.A., Ekaputri, J. E. \& Suprayitno, H. (2017). "Characteristics of Reclaimed Asphalt Material from National Road in East Java Province". Jurnal Manajemen Aset Infrastruktur \& Fasilitas, Vol. 1, No. 1, Desember 2017.

Widayanti, A., Soemitro, R.A.A., Ekaputri, J. E. \& Suprayitno, H. (2018). "Performances of Asphalt Concrete Contain Reclaimed Asphalt Pavement from National Road in East Java Province". Jurnal Manajemen Aset Infrastruktur \& Fasilitas, Vol. 2, No. 1, Maret 2018. 
Widayanti, A., Soemitro, R.A.A., Ekaputri, J. E. \& Suprayitno, H. (2012). "Economic Aspect of Reclaimed Asphalt Pavement Utilization from National Road in East Java Province". Jurnal Manajemen Aset Infrastruktur \& Fasilitas, Vol. 2, Suplemen 2, Desember 2018.

Widger, A., Skilnick, F., Zabolotnii, E. (2012). Utilization of Recycled Asphalt in Cold Mixes and Cold In-Place Recycling Processes-Guidelines. Engineer-In-Training Clifton Associated Ltd. Communities of Tomorrow, Leveraged Municipal Innovation Fund.

Xiao, F., Amirkhanian, S.N., Shen, J., Putman, B. (2009). "Influences of Crumb Rubber Size and Type on Reclaimed Asphalt Pavement (RAP) Mixtures", Construction and Building Materials 23, pp.1028-1034.

Xiao, F., Amirkhanian, Serji, J., Hsein, C. (2007). "Rutting Resistance of Rubberized Asphalt Concrete Pavements Containing Reclaimed Asphalt Pavement Mixtures", Journal of Materials in Civil Engineering, ASCE, June 2007, pp. 475-483. 
(e)ISSN 2656-8896 (p)ISSN 2656-890X

Journal of Infrastructure and Facility Asset Management - Vol. 1, Issue 1, March 2019 